\title{
P53 expression in ovarian tumors: (an immunohistochemical study)
}

\author{
Elaf Abdul-Wahab Hamdi, Shuaib H. Saleem \\ Department of Pathology, College of Medicine, University of Mosul.
}

(Ann. Coll. Med. Mosul 2012; 38 (2): 73-79).

Received: $21^{\text {st }}$ Nov. 2011; Accepted: $9^{\text {th }}$ Jul. 2012.

\begin{abstract}
Objectives: The aim of this study, first, to evaluate the frequency of immunohistochemical expression of p53 in different types of ovarian tumors, second, to correlate p53 expression with age of patients, histological type and grade of tumors, and third, to compare the results with those of others.

Methods: This study was performed on 60 primary ovarian tumors. Samples were obtained in a prospective and retrospective fashion (cross sectional study). The samples were collected from Al-Jumhuri Teaching Hospital, Al-Salaam General Hospital, Al-Khansaa Teaching Hospital, and some private Laboratories, during a period of eight months, from June 2009 through January 2010. P53 expression was assessed immunohistochemically.

Results: The patients' age ranged from 13 to 80 years, with a mean of 43.88 year. Most of them were in the fifth decade $(28.3 \%)$. Data concerning the age were missing in five patients. P53 immunoreactivity was observed in $48.1 \%$ of the malignant tumors. It was positive in 13 of 20 cases of serous adenocarcinoma, in all of the 5 cases of mucinous adenocarcinoma, in 3 of 12 granulosa cell tumors, in 2 of 4 endometrioid carcinomas, in 1 of 3 clear cell carcinoma, in 1 of 2 dysgerminomas, and in the one case of Sertoli-Leydig cell tumor. It was negative in malignant thecoma, malignant teratoma and in all borderline and benign tumors.

Statistically p53 expression was not significantly related to the age of the patients, grade, or to the histological type of the tumors. It was mainly found in malignant serous tumors $(50 \%)$, in the poorly differentiated tumors $(47.6 \%)$, and in the $6^{\text {th }}$ decade of age $(30.8 \%)$.

Conclusions: P53 was expressed in $48.1 \%$ of malignant ovarian tumors, $80.8 \%$ were epithelial tumors, $15.4 \%$ were sex cord-stromal tumors, and $3.8 \%$ were germ cell tumors, and it was negative in benign and borderline tumors.
\end{abstract}

Keywords: Ovarian tumors, p53 expression, immunohistochemistry

الخملاصة

الأهداف: تم إجر اء هذه الدر اسة لتقييم حالة الظهور المناعي لبروتين p53 في أور ام المبيض في مدينة الموصل و الربط بينها وبين

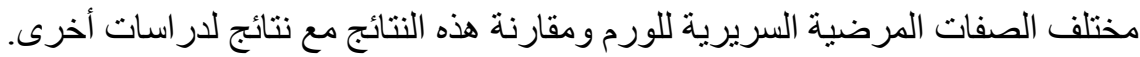

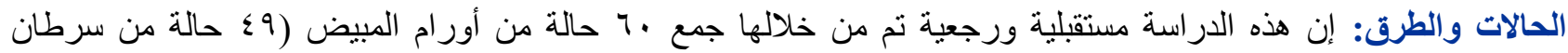

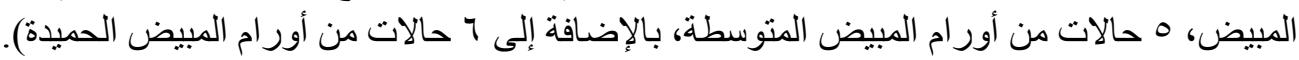

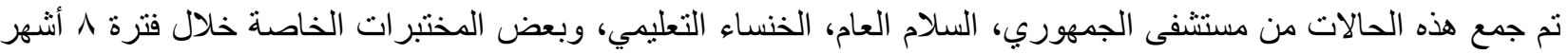

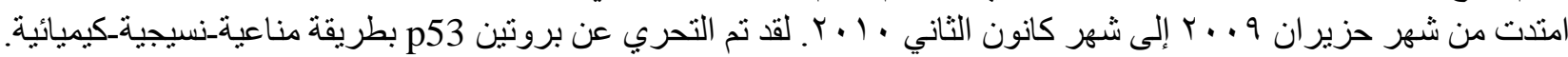

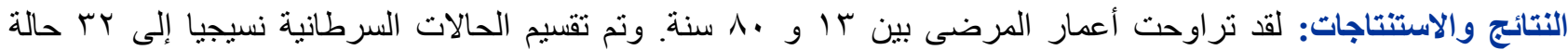

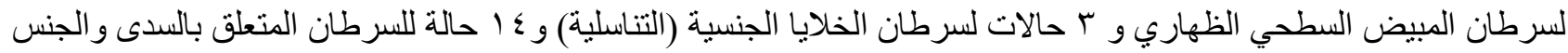

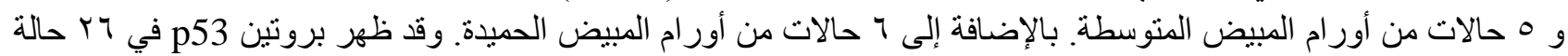

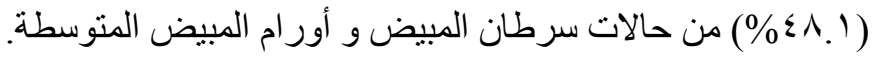


لم يكن هناك علاقة معنوية بين ظهور بروتين P53 و وعمر المريضة أو مرتبة الورم أو النوع النسيجي المرضي للورم

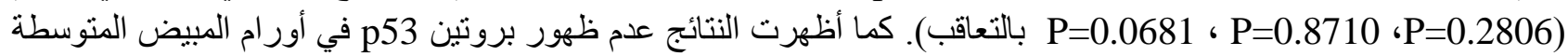

$\mathrm{O}$ varian cancer represents the sixth most commonly diagnosed cancer among women in the world, and causes more deaths per year than any other cancer of the female reproductive system $^{(1-3)}$

Ovarian cancers represent one fourth of the malignancies of the female genital $\operatorname{tract}^{(2,3)}$. They account for $4 \%$ of the total cancers in women in the United States ${ }^{(2,3)}$, ranked behind malignant neoplasms of the lung, breast, colon and uterus ${ }^{(3)}$. In Iraq, ovarian cancer ranks sixth among the most common ten cancers involving females ${ }^{(4)}$, representing about $3.2 \%$ of all female cancers, and second to cervical carcinoma in the female genital tract ${ }^{(5)}$. Since the p53 tumor suppressor gene has been found to be mutated in more than $50 \%$ of human cancers, it has attracted the interest of numerous researchers ${ }^{(6)}$. P53 is mutated and consequently overexpressed in $50 \%$ to $60 \%$ of advanced ovarian cancers ${ }^{(7)}$. P53 is rarely mutated in borderline tumors, and when this mutation occurs, it is associated with a poor prognosis ${ }^{(7)}$. The pattern of p53 abnormalities is most consistent with spontaneous mutation rather than the activity of chemical carcinogens ${ }^{(7)}$.

The aim of this study is to evaluate the frequency of p53 expression in different types of ovarian tumors, to correlate p53 expression with age of patients, histological type and grade of tumors, and to compare the results with those of others.

\section{PATIENTS AND METHODS}

\section{Selection of Cases}

This study is based on samples prospectively and retrospectively collected from 60 patients with primary ovarian tumors, of which: 32 cases were malignant epithelial tumors, 14 malignant sex cordstromal cell tumors, 3 malignant germ cell tumors, 5 borderline tumors, and 6 cases of benign tumors. Samples were collected from Al-Jumhuri Teaching Hospital, Al-Salaam General Hospital, Al-Khansaa Teaching Hospital and some private Laboratories. Expression of p53 protein by immunohistochemical staining was studied and compared in relation to patient's age, histopathological type and grade of tumors.

Hematoxylene and eosin stained slides from formalin-fixed paraffin-embedded biopsy blocks were examined. P53 expression was assessed immunohistochemically on formalin-fixed paraffinembedded tissues, using p53 (DAKO, mouse monoclonal antibody p53-clone DO-7), and Secondary red Envision system.

Immunohistochemical staining interpretation A semi-quantitative histochemical score was used to record results of p53 nuclear staining ${ }^{(8)}$. More than 1000 tumor cells, in multiple high power fields, had been counted for assessing the percentage. Also the average staining intensity was considered. The slides were checked more than once to exclude subjectivity.

P53 scoring guidelines "semi-quantitative score" ${ }^{\prime \prime(9)}$ :

I- The percentage was used to score a slide semi quantitatively in one of five categories:

\begin{tabular}{|c|c|}
\hline Proportion score (PS) & $\begin{array}{c}\text { Proportional score } \\
\text { observation }\end{array}$ \\
\hline 0 & $<5 \%$ positive cells. \\
\hline 1 & $5 \%-25 \%$ positive cells. \\
\hline 2 & $26-50 \%$ positive cells. \\
\hline 3 & $51 \%-75 \%$ positive cells. \\
\hline 4 & $76 \%-100 \%$ positive cells. \\
\hline
\end{tabular}

II- Based on the intensity of positive reaction in the majority of tumor cells, the intensity of staining is graded and scored as:

\begin{tabular}{|c|c|}
\hline Intensity score (IS) & $\begin{array}{c}\text { Intensity score } \\
\text { observation }\end{array}$ \\
\hline 1 & Weak staining (+) \\
\hline 2 & Moderate staining (++) \\
\hline 3 & Strong staining (+++) \\
\hline
\end{tabular}

Positive and negative control slides were included in each run of staining. Positive control slides were prepared from a case known to be positive for $p 53$. While negative control slides were prepared from the same tissue block incubated with Tris Buffered Saline (TBS) instead of the primary antibody. 


\section{Statistical analysis}

The relationship between p53 expression and the clinicopathologic variables was analyzed by the Fisher Freeman Holton's test. The results were considered statistically significant if the $p$ value was $<0.05$.

\section{RESULTS}

For a period of 8 months (from June 2009 through January 2010), immunohistochemical study to assess the expression of p53 protein in 60 specimens from patients with primary ovarian tumors was performed.

The patients' age was in the range of 13 to 80 years, with a mean of 43.88 year. Most of them were in the fifth decade (31.5\%), (Table 1). However, data concerning the age were missing in 5 patients.

Ovarian tumors were grouped according to their biologic behavior as: malignant tumors 49 cases $(81.7 \%)$, borderline tumors 5 cases $(8.3 \%)$, and benign tumors 6 cases (10\%). All of the tumors that expressed P53 were from malignant type (Figure 1). P53 was expressed in $80.8 \%$ in carcinomas, $15.4 \%$ in sexcord- stromal tumors, and $3.8 \%$ in germ cell tumors.

P53 was positive in 13 of 20 cases of serous adenocarcinoma (Figure 2), in all of the 5 cases of mucinous adenocarcinoma (Figure 3), in 3 of 12 granulosa cell tumors (Figure 4), in 2 of 4 endometrioid carcinomas (Figure 5), in 1 of 3 clear cell carcinoma (Figure 6), in 1 of 2 dysgerminomas (Figure 7), and in the one case of Sertoli-Leydig cell tumor (Figure 8). It was negative in malignant thecoma, malignant teratoma, in all borderline (3 serous cyst tumors and 2 mucinous cyst tumors), and in the 6 cases of benign tumors ( 2 serous cystadenoma, 2 mature teratoma, 1 mucinous cystadenoma, and 1 thecoma), (Table 2 ).

Most of the cases of malignant epithelial tumors were categorized as grade III (50\%). Grade II and grade I formed (28.1\%) and (21.9\%) respectively, (Figure 9).

\section{P53 expression}

The p53 expression was found in $48.1 \%$ of the malignant and borderline ovarian tumor cases.

\section{P53 expression and patient's age}

The p53 expression had no significant correlation to age, 5 samples were excluded because of unknown age, (Table 1).

P53 expression and histological type of the tumors

The p53 expression had no significant correlation to histological type of the tumors, (Table 2).

Table 1. P53 status in malignant ovarian tumors in relation to patients' age.

\begin{tabular}{|c|c|c|c|c|c|c|c|}
\hline \multirow{2}{*}{$\begin{array}{c}\text { Age } \\
\text { (year) }\end{array}$} & \multicolumn{2}{|c|}{ Total } & \multicolumn{2}{|c|}{ +ve } & \multicolumn{2}{|c|}{-ve } & \multirow{2}{*}{$\begin{array}{c}\text { p- } \\
\text { value }\end{array}$} \\
\hline & No. & $\%$ & No. & $\%$ & No. & $\%$ & \\
\hline $13-20$ & 3 & $5.6 \%$ & 3 & $11.5 \%$ & 0 & $0 \%$ & \\
\hline $21-30$ & 5 & $9.3 \%$ & 3 & $11.5 \%$ & 2 & $7.1 \%$ & \multirow{6}{*}{$\begin{array}{c}0.2806 \\
(\mathrm{NS})\end{array}$} \\
\hline $31-40$ & 6 & $11.1 \%$ & 2 & $7.7 \%$ & 4 & $14.4 \%$ & \\
\hline $41-50$ & 17 & $31.5 \%$ & 6 & $23.1 \%$ & 11 & $39.3 \%$ & \\
\hline $51-60$ & 15 & $27.7 \%$ & 8 & $30.9 \%$ & 7 & $25 \%$ & \\
\hline $61-70$ & 1 & $1.8 \%$ & 1 & $3.8 \%$ & 0 & $0 \%$ & \\
\hline $71-80$ & 2 & $3.7 \%$ & 0 & $0 \%$ & 2 & $7.1 \%$ & \\
\hline Unknown & 5 & $9.3 \%$ & 3 & $11.5 \%$ & 2 & $7.1 \%$ & \\
\hline Total & 54 & $100 \%$ & 26 & $48.1 \%$ & 28 & $51.9 \%$ & \\
\hline
\end{tabular}

Table 2. P53 expression and histological type of malignant and borderline ovarian tumors.

\begin{tabular}{|c|c|c|c|c|c|c|c|}
\hline \multirow{2}{*}{ Histological type of tumor } & \multicolumn{2}{|c|}{ Total } & \multicolumn{2}{|c|}{ P53 +ve } & \multicolumn{2}{|c|}{ P53 -ve } & \multirow{2}{*}{ p-value } \\
\hline & No. & $\%$ & No. & $\%$ & No. & $\%$ & \\
\hline Serous & 20 & $37 \%$ & 13 & $50 \%$ & 7 & $25 \%$ & \\
\hline Mucinous & 5 & $9.3 \%$ & 5 & $19.3 \%$ & 0 & $0 \%$ & \multirow{10}{*}{$\begin{array}{c}0.0681 \\
(N S)\end{array}$} \\
\hline Endometroid & 4 & $7.5 \%$ & 2 & $7.7 \%$ & 2 & $7.1 \%$ & \\
\hline Clear cell & 3 & $5.6 \%$ & 1 & $3.8 \%$ & 2 & $7.1 \%$ & \\
\hline Granulosa cell & 12 & $22.2 \%$ & 3 & $11.5 \%$ & 9 & $32.2 \%$ & \\
\hline Malignant thecoma & 1 & $1.8 \%$ & 0 & $0 \%$ & 1 & $3.6 \%$ & \\
\hline Sertoli-Leydig cell & 1 & $1.8 \%$ & 1 & $3.8 \%$ & 0 & $0 \%$ & \\
\hline Malignant teratoma & 1 & $1.8 \%$ & 0 & $0 \%$ & 1 & $3.6 \%$ & \\
\hline Dysgerminoma & 2 & $3.7 \%$ & 1 & $3.8 \%$ & 1 & $3.6 \%$ & \\
\hline Borderline serous cyst tumor & 3 & $5.6 \%$ & 0 & $0 \%$ & 3 & $10.7 \%$ & \\
\hline Borderline mucinous cyst tumor & 2 & $3.7 \%$ & 0 & $0 \%$ & 2 & $7.1 \%$ & \\
\hline $\begin{array}{r}\text { Total } \\
\end{array}$ & 54 & $100 \%$ & 26 & $48.1 \%$ & 28 & $51.9 \%$ & \\
\hline
\end{tabular}




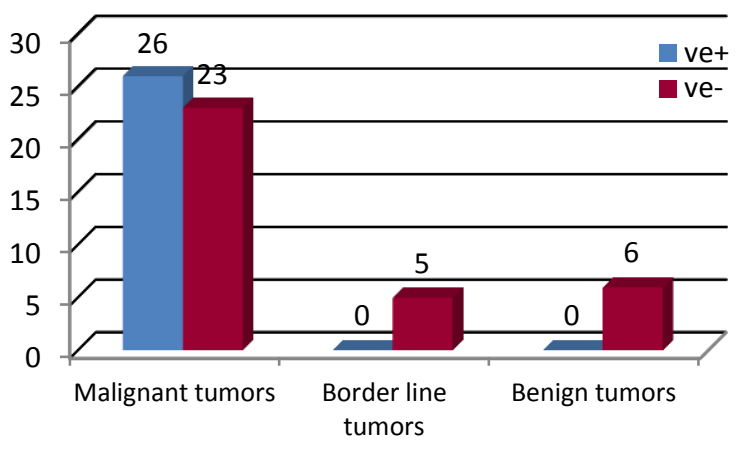

Figure 1. P53 status in ovarian tumors.

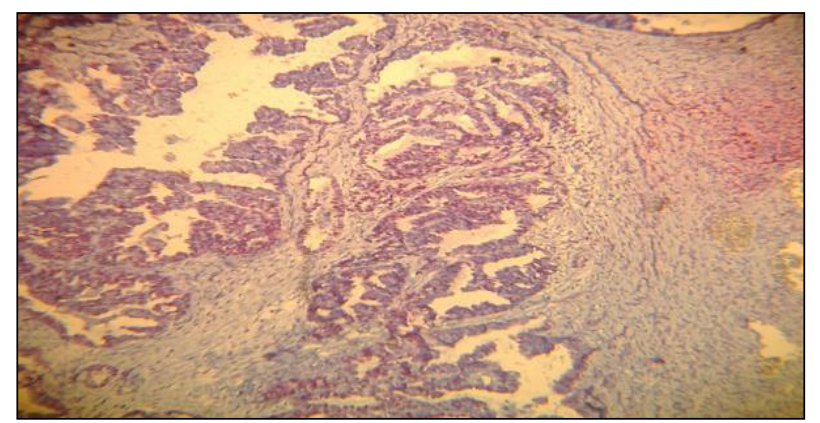

Figure 2. Papillary serous cystadenocarcinoma, IHC staining positive for p53 protein, strong expression ( $x$ 100).

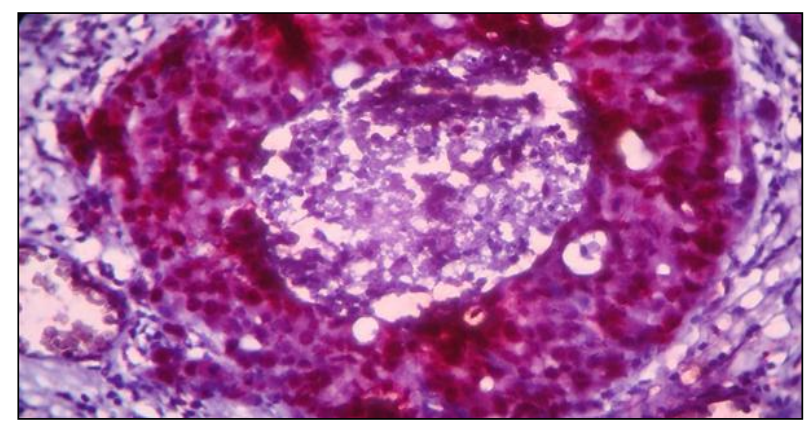

Figure 3. Mucinous cystadenocarcinoma of ovary, IHC staining positive for p53 protein, strong expression ( $x$ 400).

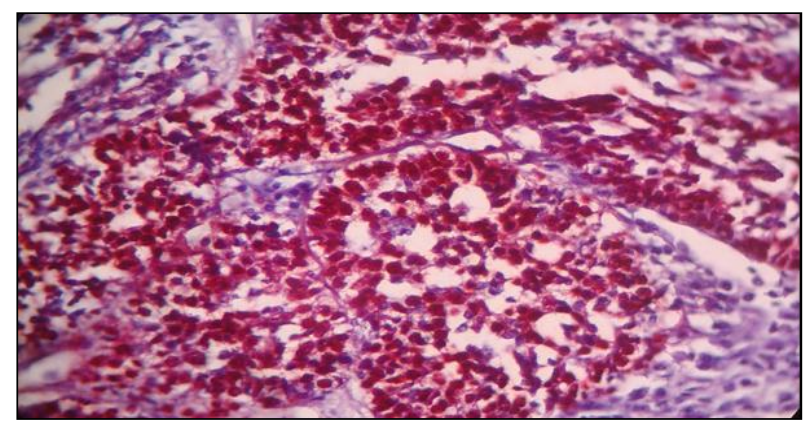

Figure 4. Granulosa cell tumor, IHC staining positive for p53 protein, strong intensity (x 400).

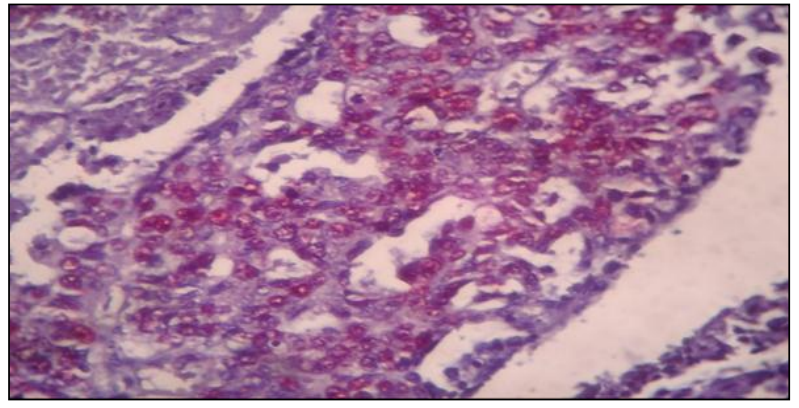

Figure 5. Endometrioid carcinoma grade II, IHC staining positive for p53 protein, moderate intensity $(x 400)$.

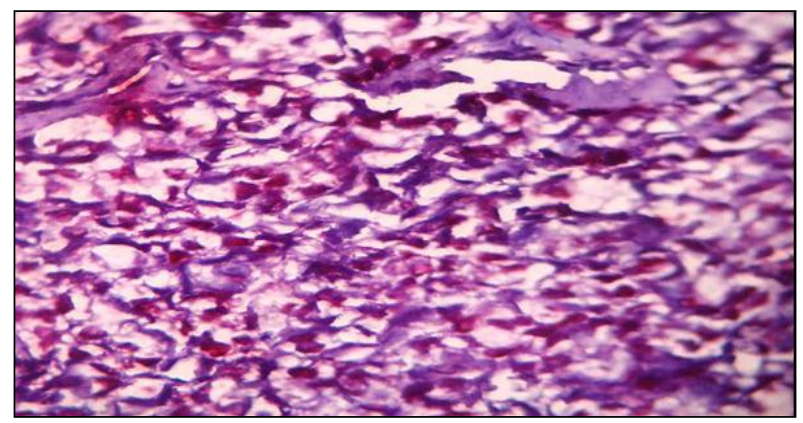

Figure 6. Clear cell carcinoma of ovary, IHC staining positive for p53 protein (x 400).

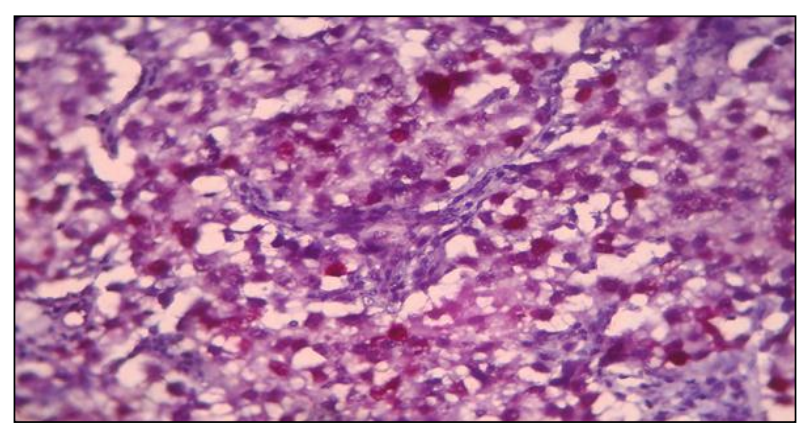

Figure 7. Dysgerminoma, IHC staining positive for p53 protein, scaterred positivity (x 400).

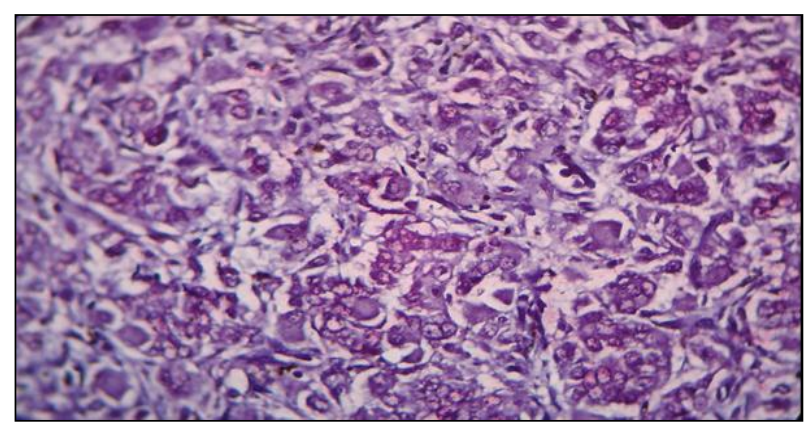

Figure 8. Sertoli-Leydig cell, IHC staining positive for p53 protein weak intensity (x 400).

P53 expression and grade of the carcinomas P53 expression has no significant correlation to the grade of the tumors $p$-value $=0.8710(\mathrm{NS})$, (Figure 9). 


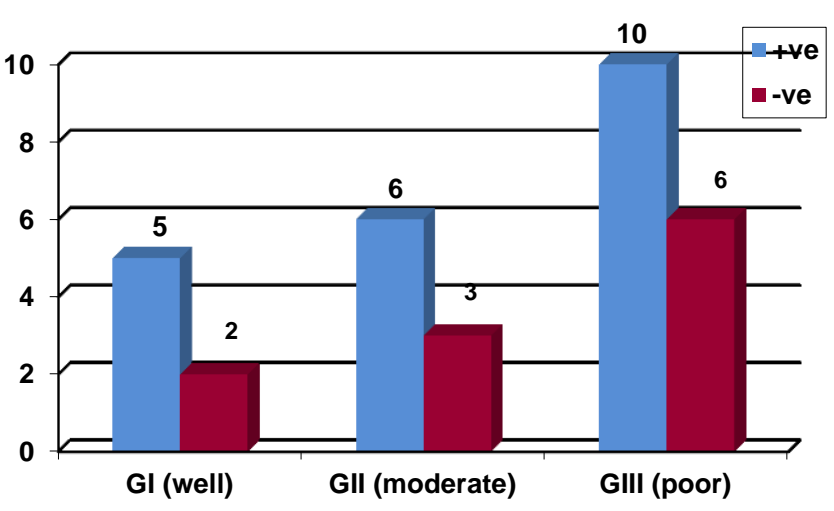

Figure 9. P53 expression \& grade of ovarian carcinomas $(P=0.8710, N S)$.

\section{DISCUSSION}

In this study, p53 was expressed in $48.1 \%$ of the malignant ovarian tumors. Other similar studies have shown variable ratios (25.6\%-61\%) (Table 3). The reasons for this variation are unknown ${ }^{(10)}$. However possible sources for this variation may be attributed to ${ }^{(10)}$ :

a. The properties of different antibodies.

b. The scoring methods applied for p53 immunoreactivity.

c. The enzyme and microwave treatments of the tissue during the staining process.

d. The tissue fixation procedure.

Table 3. Frequency of p53 expression in ovarian tumors in different studies.

\begin{tabular}{|c|c|c|c|c|}
\hline Study & Year & Site & $\begin{array}{l}\text { No. of } \\
\text { Cases }\end{array}$ & $\begin{array}{c}\text { \% of } \\
\text { P53 +ve } \\
\text { Cases }\end{array}$ \\
\hline Current study & 2010 & Mosul & 54 & $48.1 \%$ \\
\hline Abubaker J. et al ${ }^{(11)}$. & 2009 & $\begin{array}{l}\text { Saudi } \\
\text { Arabia }\end{array}$ & 154 & $32.5 \%$ \\
\hline $\begin{array}{l}\text { Kupryjanczyk J. et } \\
\mathrm{al}^{(12)}\end{array}$ & 2008 & Poland & 452 & $58.8 \%$ \\
\hline Shao HL. et $a^{(13)}$. & 2007 & China & 79 & $28.3 \%$ \\
\hline Graeff P. et al ${ }^{(14)}$. & 2006 & UK & 476 & $52.1 \%$ \\
\hline Dogan E. et al ${ }^{(15)}$. & 2005 & Turkey & 82 & $54 \%$ \\
\hline Nielsen JS. et al ${ }^{(16)}$. & 2004 & Denmark & 868 & $53 \%$ \\
\hline $\begin{array}{l}\text { Havrilesky L. et } \\
\text { al }^{(17)} \text {. }\end{array}$ & 2003 & USA & 125 & $44 \%$ \\
\hline Chan WY. et al ${ }^{(18)}$ & 2000 & China & 46 & $54 \%$ \\
\hline $\begin{array}{l}\text { Ferrandina G. et al } \\
\text { (19). }\end{array}$ & 1999 & Italy & 168 & $50 \%$ \\
\hline Anttila MA. et $\mathrm{al}^{(20)}$. & 1998 & Finland & 316 & $25.6 \%$ \\
\hline $\begin{array}{l}\text { Eltabbakh GH. et } \\
\mathrm{al}^{(21)} \text {. }\end{array}$ & 1997 & NewYork & 221 & $48.4 \%$ \\
\hline Herod J J. et al ${ }^{(22)}$. & 1996 & UK & 70 & $61 \%$ \\
\hline Klemi PJ. et $\mathrm{al}^{(23)}$ & 1995 & Finland & 136 & $46.3 \%$ \\
\hline Marks JR. et al ${ }^{(24)}$. & 1991 & $\begin{array}{c}\text { North } \\
\text { carolina }\end{array}$ & 107 & $50 \%$ \\
\hline
\end{tabular}

\section{P53 expression in relation to age}

P53 expression was mainly found in the $6^{\text {th }}$ decade of life $(30.9 \%)$. This may be related to the accumulation of somatic mutations ${ }^{(25)}$. It is known that loss of heterozygosity on chromosome 17 increases with age ${ }^{(25)}$. Li-Fraumeni patients with p53 mutations develop tumors earlier and with a higher frequency when adjusted for age ${ }^{(26)}$. The promoter of MDM2 (Murine Double Minut2) and p53 interaction partner contains a functional estrogen receptor signal in the DNA ${ }^{(27)}$. Therefore, the effect of the p53 on risk of cancer in women could depend on menopausal status ${ }^{(27)}$.

Statistically, there was no significant correlation between p53 overexpression and age of the patients. This is consistent with the results of other studies $^{(12,14,19,20,22,23,26)}$, with the exception of a single one with a reported significant correlation ${ }^{(21)}$.

\section{P53 expression in relation to histological type of tumors}

Our study showed p53 expression in carcinomas mainly, this was reported by others who found that surface epithelial tumors, especially serous cystadenocarcinomas, and non Hodgkin lymphomas of the ovary showed high expression of p53 compared to the benign and borderline tumors $^{(28)}$. On the otherhand, the expression of p53 in tumors arising from germ cells and sexcordstromal cells were observed to be very low ${ }^{(28)}$. P53 deficiency alone is not sufficient for ovarian epithelial tumorigenesis ${ }^{(29)}$. Thus, other genetic lesions are likely to be required to develop ovarian cancer $^{(29)}$. However, the leading role of alterations in p53 gene in the development of ovarian carcinoma was further substantiated by results of a study, which revealed a striking association between the number of life time ovulatory cycles and overexpression of mutant p53 protein in ovarian carcinoma tissue ${ }^{(30)}$. Abendstein $\mathrm{B}$, et al. suggested that p53 mutations occur spontaneously during the repeated injuries of the ovarian surface caused by ovulations ${ }^{(30)}$. This repeated repair requires high rates of DNA synthesis with increased likelihood of mutations especially in the ovarian surface epithelium from which epithelial ovarian carcinomas originate ${ }^{(30)}$.

Statistically, there was no significant correlation between p53 expression and histological type of tumors. Review of literature showed conflicting results; some with no significant relation- 
ship $^{(13,16,18,25)}$ and others with significant relationship ${ }^{(12,20,22,23)}$.

\section{P53 expression in relation to grade of tumors}

It has been well established that TP53 mutations are frequent in both hereditary and sporadic highgrade serous carcinoma ${ }^{(29,31-34)}$. Boyd and coworkers $^{(35)}$ demonstrated TP53 mutations in microcarcinomas, and Werness et $\mathrm{al}^{\left({ }^{(36)}\right.}$ demonstrated loss of heterozygosity at BRCA1 and TP53 and expression of p53 in one microscopic ovarian surface carcinoma-in situ ${ }^{(36)}$.

These data demonstrating increasing atypia and accumulating genetic alterations in surface epithelial inclusion glands, ovarian "carcinoma in situ", microcarcinomas, and typical high-grade serous carcinoma, suggest that high-grade serous and perhaps endometrioid ovarian adenocarcinomas arise from these structures ${ }^{(35)}$. Additionally, the data from a small number of cases indicate that TP53 mutation occurs in preinvasive epithelium with loss of BRCA1 or BRCA2 function in the majority of tumors, findings compatible with the high degree of genetic instability of these tumors ${ }^{(35)}$.

In the present study P53 expression was mainly found in poorly differentiated tumors (47.6\%). However, the expression of p53 in relation to grade was not significant statistically and this is also shown in three other studies ${ }^{(11,22,37)}$ but it was significant in eight studies $^{(12,14,16,18-21,23,26)}$ which reported significant correlation with higher grades while Havrilesky et al. ${ }^{(17)}$ reported significant correlation with lower grade, which is attributed to the fact that most of their cases were in lower grade.

The degree of p53 expression increased with the increasing grade of ovarian tumors, as seen by the presence of strong p53 expression in grade III ${ }^{211}$. Apparently, cancers with p53 mutation demonstrated a trend toward more aggressive tumor behavior such as distant metastasis and poor cellular differentiation ${ }^{(38)}$. A better understanding of the factors and mechanisms determining the aggressive behavior of some epithelial ovarian carcinoma is critical in developing new treatment ${ }^{(11)}$.

\section{CONCLUSIONS}

1. P53 expression was found in $48.1 \%$ of malignant ovarian tumors, and this result is within the range observed by others.

2. P53 was expressed in $80.8 \%$ in carcinomas, $15.4 \%$ in sexcord-stromal tumors, and $3.8 \%$ in germ cell tumors.

3. Age of the patients, grade, and histological type of the tumors had no significant correlation with $\mathrm{p} 53$ expression.

4. All of the benign and the borderline tumors were negative for $\mathrm{p} 53$.

\section{REFERENCES}

1. Permuth-Wey J, Sellers TA. "Epidemiology of ovarian cancer". Methods in Molecular Biology 2009; 472: 413-437.

2. Elattar I. Cancer in the Arab World: Magnitude of the Problem. UICC 2005; 21-25.

3. Jemal A, Murray T, Thun M. Cancer Statistics. Cancer J Clin 2003; 53: 5-26.

4. Ministry of health. Results of Iraqi cancer registry, 2001.

5. Yahya TT. Ovarian Tumours Pathological Prospective Study In Mosul. A Thesis Submitted in Partial Fulfillment of the Requirement for the Degree of Iraqi Board for Medical Specialization In Pathology. 2005, College of medicine/ University of Mosul.

6. Efeyan A, Serrano M. P53: guardian of the genome and policeman of the oncogenes. Cell Cycle 2007; 6(9):1006-1010.

7. Berek JS, Bast RC. Ovarian Cancer. In: Cancer Medicine. $6^{\text {th }}$ edition, Hamilton, Ontario: BC Decker Inc, 2003.p. 314-329.

8. Gershenson DM, Deavers M, Diaz S, et al. Prognostic Significance of p53 Expression in Advanced-Stage Ovarian Serous Borderline Tumors. Clinical Cancer Research 1999; 5: 40534058.

9. Gershenson DM, Deavers M, Diaz S, et al. Prognostic Significance of p53 Expression in Advanced-Stage Ovarian Serous Borderline Tumors. Clinical Cancer Research 1999; 5: 40534058.

10. Astanehe A, Arenillas D, Wasserman WW, et al. Mechanisms underlying p53 regulation of PIK3CA transcription in ovarian surface epithelium and in ovarian cancer. Journal of Cell Science 2008; 121 : 664-674.

11. Abubaker J, Bavi P, Al-Haqawi W, et al. PIK3CA alterations in middle eastern ovarian cancers. Molecular Cancer 2009;8: 51. [abstract] 
12. Kupryjanczyk J, Kraszewska E, Seta Z, et al. TP53 status and taxane-platinum versus platinum-based therapy in ovarian cancer patients: a nonrandomized retrospective study. BMC Cancer 2008; 8(27): 1471-2407.

13. Shao HL, Shen DH, Xue WC, et al. Clinicopathologic analysis and expression of cyclin D1 and p53 of ovarian borderline tumors and carcinomas. Zhonghua Fu Chan Ke Za Zhi 2007; 42(4): 227-232.

14. Graeff $P$, Hall J, Crijns AP, et al. Factors influencing p53 expression in ovarian cancer as a biomarker of clinical outcome in multicentre studies. $\mathrm{Br} \mathrm{J}$ Cancer 2006; 95(5): 627-633.

15. Dogan E, Saygili U, Tuna B, et al. p53 and MDM2 as prognostic indicators in patients with epithelial ovarian cancer: a multivariate analysis. Gynecol Oncol. 2005; 97(1): 46-52.

16. Nielsen JS, Jakobsen E, Hølund B, et al. Prognostic significance of p53, Her-2, and EGFR overexpression in borderline and epithelial ovarian cancer. Int J Gynecol Cancer 2004; 14(6): 10861096.

17. Havrilesky L, Darcy KM, Hamdan $H$, et al. Prognostic significances of p53 mutation and p53 overexpression in Advanced Epithelial Ovarian Cancer: A Gynecologic Oncology Group Study. Journal of Clinical Oncology 2003; 21(20): 38143825.

18. Chan WY, Cheung KK, Schorge JO, et al. Bcl-2 and p53 Protein Expression, Apoptosis, and p53 Mutation in Human Epithelial Ovarian Cancers. Am J Pathol 2000; 156: 409-417.

19. Ferrandina G, Fagotti A, Salerno MG, et al. p53 overexpression is associated with cytoreduction and response to chemotherapy in ovarian cancer. $\mathrm{Br} J$ Cancer 1999; 81(4): 733-740.

20. Anttila MA, Kosma VM, Hongxiu J, et al. P21/waf1 expression as related to $\mathrm{p} 53$, cell proliferation and prognosis in epithelial ovarian cancer. $\mathrm{Br} \mathrm{J}$ Cancer 1998; 79(11-12): 1870-1878.

21. Eltabbakh GH, Belinson JL, Kennedy AW, et al. p53 overexpression is not an independent prognostic factor for patients with primary ovarian epithelial cancer. Cancer 1997; 80(5): 892-898.

22. Herod JJ, Eliopoulos AG, Warwick J, et al. The Prognostic Significance of Bcl-2 and p53 Expression in Ovarian Carcinoma. Cancer Research 1996; 56: 2178-2184.

23. Klemi PJ, Pylkanen L, Kiilholma P, et al. P53 protein Detected by immunohistochemistry as a prognostic factor in patients with epithelial ovarian carcinoma. Cancer 1995; 76(7): 1201-1208.

24. Marks JR, Davidoff AM, Kerns BJ, et al. Overexpression and Mutation of p53 in Epithelial
Ovarian Cancer. Cancer Research 1991; 51(11), 2979-2984.

25. Agrawal V, Gautam R. Prognostic Factors of Ovarian Cancers. [cited 2009 April 12]. Available from:URL:http://www.obgyn.net/educationaltutorials/ agrawal01/Prognostic_Factors_of_Ovarian_Cancer. ppt\#338,8.

26. Wu CC, Shete S, Amos Cl, et al. Joint effects of germ-line p53 mutation and sex on cancer risk in $\mathrm{Li}$ Fraumeni syndrome. Cancer Res. 2006; 66: 82878292.

27. Ørsted DD, Bojesen SE, Hansen AT, et al. Tumor suppressor p53 Arg72Pro polymorphism and longevity, cancer survival, and risk of cancer in the general population. JEM 2007; 204 (6): 1295 -1301.

28. Rajesh NG, Rekha K, Krishna B. Significance of p53 expression in ovarian tumors and its correlation to the morphological differentiation. Indian $\mathrm{J}$ Pathol Microbiol 2007; 50(2): 284-287.

29. Chen CM, Chang JL, Behringer RR. Tumor formation in p53 mutant ovaries transplanted into wild-type female hosts. Oncogene 2004; 23: 77227725.

30. Abendstein B, Marth C, Müller-Holzner E, et al. Clinical significance of serum and ascitic p53 autoantibodies in epithelial ovarian carcinoma. Cancer 2000; 88(6): 1432-1437.

31. Nnene IO, Nieto JJ, Crow JC, et al. Cell cycle and apoptotic proteins in relation to ovarian epithelial morphology. Gynecol Oncol 2004; 92: 247-251.

32. Singer G, Oldt R, Cohen $Y$, et al. Mutations in BRAF and KRAS characterize the development of lowgrade ovarian serous carcinoma. J Nat Cancer Inst 2003; 95: 484-486.

33. Chan WY, Cheung KK, Schorge JO, et al. Bc1-2 and p53 protein expression, apoptosis, and p53 mutation in human epithelial ovarian cancers. Am J Pathol. 2000;156: 409-417.

34. Caduff R, Svoboda NS, Ferguson A, et al. Comparison of mutations of Ki-Ras and p53 immunoreactivity in borderline and malignant epithelial ovarian tumors. Am J Surg Pathol 2001; 23: 323-328.

35. Bell DA. Origins and molecular pathology of ovarian cancer. Modern Pathology 2005; 18, S19-S32.

36. Werness BA, Parvatiyar P, Ramus SJ, et al. Ovarian carcinoma in situ with germline BRCA1 mutation and loss of heterozygosity at BRCA1 and TP53. J Natl Cancer Inst 2000; 92: 1088-1091.

37. Seppa N. Ovulation Cycles Linked to Ovarian Cancer. Science News 1997; 152(1): 7.

38. Rose SL, Robertson AD, Goodheart MJ, et al. The Impact of p53 Protein Core Domain Structural Alteration on Ovarian Cancer Survival. Clinical Cancer Research 2003; 9: 4139-4144. 